\title{
A Short Course on Development in "Post-conflict" Congo
}

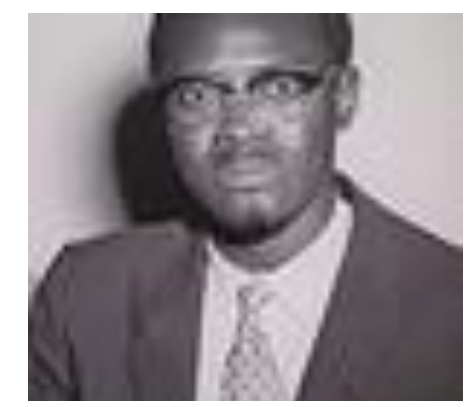

PATRICE LUMUMBA | LIBRARY OF CONGRESS

\author{
By Justin Podur
}

$\mathrm{I}$ t was during my brief teaching in Bukavu, in the east of the Democratic Republic of Congo (DRC), that I came to understand the power of neoliberalism in shaping the narrative of DRC's past, present, and future. While my students argued that the DRC's problems stemmed from local corruption, not ongoing colonialism, I was trying to present a more diverse story of development, one that cracks the neoliberal narrative and lets democracy and the public sector play a role.

It was the summer of 2011 and I was teaching the very first class of a new Master's Program in Environmental Management. Most of my students were managers in government or non-governmental organizations, or teachers upgrading their skills for jobs they already held. Mostly in their 30s and 40s, they are also survivors of one of the worst conflicts of the century, and they all have stories of which I got only small glimpses.
For them, having a foreign professor was a chance to see how their education compares with the rest of the world's in both content and standards. But my own task was different. My two short courses, "Globalization and Development" and "Geographic Information Systems (GIS) and Forest Management," were to help these current and future environmental managers expand their understanding of the policy options available to themoptions shaped by their history.

The DRC only became independent in 1960. Its independence was immediately followed by an invasion by its former colonial master, Belgium, followed by an intervention by the United States. Decades of kleptocratic dictatorship under Mobutu followed, ending only through yet another foreign invasion, this time by Rwanda in 1996, and Rwanda continues to call the shots in the eastern Congo, where I was. Given this history, the Congo never had a chance to recover from the damage inflicted upon it 
by colonialism; instead, it has been continuously tortured by it.

\section{The DRC only became independent in 1960. Its independence was immediately followed by an invasion by its former colonial master, Belgium, followed by an intervention by the United States.}

The Congo's education system is no exception. By favoring vocational education over higher education, the Belgians sought to prevent the emergence of a Congolese elite that could challenge their rule. A Belgian colonial official wrote: "If we have no black doctors, veterinarians, engineers, it is because we can send white doctors, veterinarians, and engineers." ${ }^{1}$ In about fifty years of colonial rule the Belgians produced virtually no Congolese university graduates. By 1954, there were 30 Africans enrolled in Congolese universities; by 1959, the Belgians increased enrolment to a total of 421 Africans studying at Congolese universities. ${ }^{2}$ (The population at the time was about 14 million). An American observer in 1946 wrote: "Only if it is intended that the Congolese people remain permanently under European tutelage, can a disjointed system of education, which denies them effective training beyond the rudimentary and limited vocational levels, be justified. ${ }^{3}$

Had the Congo had time to recover, these legacies would be irrelevant. But as it stands, both the colonial legacy and current strife hinder everyday educational work.

\section{The day-to-day difficulties}

The day-to-day difficulties of my Congolese students are very different from those on North American campuses. My class nominally starts at $1 \mathrm{pm}$, but we never get going before 1:30. The campus is in Panzi, a remote part of town, and to get to it you have to take a dirt road that is narrow and completely jammed with people, cars, motorcycles, buses, and trucks, at all hours. One day someone suggests that my class change to $10 \mathrm{am}$, and a vigorous debate starts. They call a vote and it's split. I break the tie, telling the class that I have decided to do it at $1 \mathrm{pm}$, hoping that I'm guessing right, and they all seem satisfied - until the next day, when the debate ensues again. They all work, and their other classes are just as packed and intense as mine, because professors are coming from other countries like Burundi and Kenya and can only teach at UEA (I'Université Evangelique en Afrique) while they are on leave, like me.

For their assignments, which they call "Travails Pratiques," some give me hand-written versions, others email them or hand me printed copies, and still others seek extensions on the grounds that there was no electricity the night before. The city is powered by an unreliable hydroelectric generator on the Ruzizi River, and I live through the nightly blackouts too, so I empathize.

One day a student arrives so late that he's missed the entire class and the rest of the students are piling into vehicles to head home. He explains he was held up at work. He is a high school teacher who needs a sound system to teach because his class has 500 students, his school 3000. I am sure I am misunderstanding the numbers, that my French comprehension is failing me. A few days later I bring it up again with a group of students. I tell them I don't think it's possible that the teacher has 500 kids in his class. They say it is. One, an architect who was once in medical school, said he was once in a class with 3500 in an auditorium.

\author{
"How do they mark assignments?" \\ "Assistants," they tell me. \\ "How many assistants?" \\ "Three!" \\ "So one assistant marks 1000 papers? How \\ long do they have?" \\ "3 months?"
}

Even if those were simple assignments, it would be twenty a day for fifty days. Another teacher admitted to me that it was virtually impossible to do the work.

The teacher in my class gets paid $\$ 175$ per month, but the average is apparently closer to $\$ 70$ a month, and only $20 \%$ of teachers are even getting paid. Public school students pay about $\$ 5$ a month, but teachers sometimes ask parents for more. Tuition in the master's program is $\$ 1500$ for the year, which includes a laptop - a smart idea by Katcho Karume, volcanologist and coordinator of the Master's program, who tells me they are paying only a fraction of the total cost per student, with the rest covered by foreign donations.

These anecdotal numbers I hear from my students contrast starkly with official statistics. A 2005 World Bank country study listed average primary school class sizes around 40, and salaries around $\$ 15$ per month (World Bank 2005, p. 87). These figures excluded the eastern Congo, however, where the war shattered the already broken system. The descriptions I heard were those of a system that is in recovery mode.

\section{Educational problems from Congo's history}

And yet, despite these significant day-to-day differences, in some ways these students remind me of my students at home - they are on Facebook in the computer lab, they look at their laptops during lectures, and they duck out of class with their cell phones. 
Given Congo's history, such similarities were even more surprising. King Leopold of Belgium took the Congo in the latter part of the $19^{\text {th }}$ century's "Scramble for Africa" in one of history's most horrific episodes of colonialism. Though the Congo became a Belgian colony (1906-1960), this more official status did not help its prospects. The Belgians left Congo in a disastrous state, including structural problems in its education sector. A study done by Barbara Yates shortly after independence found the system completely bottlenecked by personnel shortages and urgently needing to train more teachers, especially above primary schools. This study found that less than two percent of eligible young people were enrolled in secondary schools and barely one percent in higher education, and the problem is even worse once the dropout rates are included. (Yates 1963, p.153).

"Over eighty years of colonial history, Belgium managed to produce 2000 Congolese high school graduates and twenty Congolese college graduates," Yates writes (p.153). In fact, the Belgians engaged in educational colonialism. Prioritizing vocational education and semiskilled workers to assist the colonial administration, theirs was a deliberate policy of keeping the educational development of the Congolese low. In a later study Yates goes on to argue that Belgium's educational policy was based on the principles of Christian patriarchy, white hegemony, and a very specific fear that education would create an uncontrollable Congolese elite. (Yates 1980, pp.27-50)

If anything, economic and political interference in Congolese affairs continued in subsequent years. The US helped overthrow Congolese leader Patrice Lumumba and supported the thirty-five-year dictatorship of Mobutu. Under Mobutu, education as well as development more generally stagnated, while the profits of the Congo's mineral wealth flowed to South Africa, the US, and Europe. A report published by the Open Society Initiative for Southern Africa notes, among others, that the public education budget dropped from $7 \%$ of the GDP to $1 \%$, that there was a $96 \%$ fall in spending per student, and that the estimated literacy rate was lower than 70\%. (AfriMap 2009). These problems persist to this day. Schools are top heavy with staff and short of teachers and many children simply don't go to school.

Still, while colonialism and Mobutu's dictatorship are responsible for much of the current disorder, the international war that overthrew him wreaked even more devastation on the country. Bukavu, where I worked, was hit very hard by successive invasions throughout the war, notably by Rwandan refugees and by the Rwandan Patriotic Army that pursued them. Over the next 10 years, the Rwandans, their Ugandan allies, Congolese self-defense groups, and various Congolese governments fought a war conducted mostly against civilians like my students, leaving the rich mineral resources in the hands of various armed factions, and leaving people starving amid fertile agricultural land too dangerous to work. Today there is a kind of peace, though the mines remain in the hands of armed groups; civilians are still brutalized; and the devastated infrastructure is yet to be rebuilt.
Maybe that's why both Katcho Karume, the program director of my university and agronomist Gustave Mushagulusa, the rector, always seem to be in a hurry: they need to accelerate the education of a couple of generations of Congolese. One of Gustave's favourite sayings, when he's trying to move a meeting along, is "il faut gagner le temps" - - "we need to make up some time."

\section{My students were not very familiar with the narratives of anti- colonial nationalist struggle.}

Private universities were authorized in 1989, and my university is one of hundreds of such institutions created in the years that followed. Surprisingly, the enrollment ratio in higher education is higher here than in other countries in the region. According to a World Bank study, DRC's higher education system "continues to display vitality: though the resources for effective functioning are lacking, journals and publications are produced, seminars organized, and internet sites maintained" (World Bank 2005, p. 101). Yet for all this vitality, the province of South Kivu, where the UEA is located, is among the worst served (World Bank 2005, p. 105). As universities across the DRC try to "make up some time," inequality between regions is still waiting to be addressed.

\section{The power of Western stories of Congo}

Kevin C. Dunn, in his 2003 book Imagining the Congo, discusses how Western perceptions of the Congo as intrinsically chaotic, as the "heart of darkness," shaped Western policy towards the country at key moments in its history. As I interacted with my students, I realized that Western perceptions were so powerful and hegemonic that they also shaped the world views of my Congolese students, who, in my view, had suffered very directly from Western interventions over their lifetimes.

My students were familiar with Patrice Lumumba, though more as a martyr than as a political thinker; some of them knew about Frantz Fanon, but mostly just his statement that if Africa were a gun, the Congo would be the trigger; some of them knew a little bit of Marx. But after a quick poll I realized that the radical analysis I had assumed would be the starting point for a course on Globalization and Development at a university in Bukavu was not to be the starting point at all.

This made my task slightly more complex than I had planned. I walked in thinking, here in the country of Patrice Lumumba, the continent of Frantz Fanon, the radical narrative of rapacious global capitalism would be so obvious that it wouldn't even be clear what I would have to teach at all. I assumed that I would be able to add some nuances to students' thinking on these issues, some ways of thinking about globalization and economic development in other contexts that might be of value. But what I encountered was something quite different.

My students were not very familiar with the narratives of anti-colonial nationalist struggle. To meet them where 
they were at, I had to start from the discourses they were familiar with, which are those in fashion in Africa today: debates about international aid that took neoliberal economic policies for granted, without any alternatives considered. As a first step, I would have to try to introduce them to the idea that there were several ways of understanding the global economy, and that of these, the neoliberal way of understanding it was not necessarily the best.

So I start where they are at. In my development class, I start them off reading Dambisa Moyo's Dead Aid: Why Aid is Not Working and How There Is a Better Way for Africa, a book whose message is that Africans should rely on themselves and not on donors, appeals to them. Moyo argues that aid destroys small business, breaks government accountability to taxpayers, causes inflation, and feeds corruption, which is a major preoccupation of my students.

The enormity of this situation is noted in a 2009 OSISA-AfriMap report about corruption in the Congo's education system. It concludes

that corruption was endemic, including the exchange of good grades for sexual favours or for cash; the use of funds for purposes other than those they were allocated to; the straightforward theft of funds from the institutions concerned; the allocation of UNESCO scholarship funds to personal associates; misuse of institutional property or vehicles for personal purposes; discriminatory hiring practices; and the use of students to carry out work for teaching staff on a personal basis.

The report argues for a stronger institutional and political framework to address corruption in the education sector. But is corruption really just an outcome, as Moyo would argue, of failing to privilege the private sector enough? Or was it an outcome of scarcity itself?

After Moyo's book, I follow up with Ha-Joon Chang's book, Bad Samaritans: The Myth of Free Trade and the Secret History of Capitalism. As an economic historian, Chang shows that today's wealthy countries became wealthy by defying every single tenet of neoliberalism the public sector always played a leading role, and there was heavy regulation, redistribution, and planning.

After Chang, who is ultimately a Keynesian, I introduce Marx, whose name is familiar to my students but whose ideas are not. I talk about Marx's critique of capitalism and class hierarchy, and the idea that those who work should control the wealth they produce. They understand the moral appeal of these ideas, but they want practical examples and I tell them about Cuba's famed healthcare system. They know that Che Guevara was a Marxist, but they also know that Che's time in the Congo didn't amount to very much. We go back to Keynesianism.

In contrast to Moyo and the World Bank, Chang argues that corruption is a consequence of a lack of development, not a cause. A lack of development means that a government has a low tax base, which means that it can't pay good salaries to public employees who are in a position to get money in other ways. I am building up to this point in class, trying to lead the students to the answer I want, when one of them surprises me:

"So, what do you do, if you are a public servant, and your salary is too low to live on?" I ask, fully expecting someone to say: "try to get bribes." Instead:"You get a job with an NGO!"

My students' surprise answer reveals one of Moyo's arguments against foreign aid: that the international salaries paid by aid agencies make the wages of local businesses (and government) uncompetitive. I acknowledge this, but ask students to consider that direct foreign investment, which Moyo advocates, could have the exact same effect on a poor economy. Some are convinced. Others do what my Canadian students do: try to find a middle ground, as if neoliberal, Keynesian, and Marxist theories can all be right.

Another question my students want to debate is the relationship between leadership and structure. We talk about where the DRC fits into the global economy: its dependence on aid and exports of natural resources, illegal networks by which predatory neighbours capture its revenue, and how development in the DRC might involve some mix of investment in the agricultural and industrial economy, while paying attention to conservation of the DRC's extraordinary ecological heritage. However, when I introduce them to political economy ideas about how different state structures can lead to different economic outcomes, they ask: "What does the structure matter if our leaders are corrupt?"

I tell them they are the leaders now.

Katcho has the same message, phrased more harshly. "No one will do anything for you," he tells them, "and you don't want to work, you don't want to read, you don't want to do it for yourself." Go easy on them, I argue with him. I tell him they work as hard as my students in Canada.

With Congolese professor Pascal Sanginga (a development practitioner based in Kenya), Katcho and I form a panel to listen to all the Master's thesis proposals for this class: these students are about to start their research and are seeking feedback on their ideas. Katcho's feedback is accurate, but it is so blunt that it would make my Canadian students cry. After my slightly gentler comments to one student, Katcho says: "You were very diplomatic, Justin, but I don't see anything in this proposal that is actual research."

But most of the proposals are interesting, and wideranging, on issues such as renewable energy, integrated pest management, women's participation, hospital waste, and river pollution. We mostly give the usual kinds of criticisms of methodology, research question, and feasibility. 
The global economy of the Kivus

One student proposes a completely infeasible program: to study the effect of money from illegal mining on construction, and then the effect of construction on deforestation. I suggest that the relationship between construction and deforestation will be difficult enough, more than enough for a Master's thesis, and that the economy doesn't work in such a way that you can separate out mining money. Katcho agrees. "Is a professor's salary paid for by mining? Is a teacher's? Is a doctor's?"

The economy of the Kivus is dominated by a mix of United Nations, foreign donors, and the somewhat dysfunctional mining sector. While much of the mining is still controlled by armed groups linked either to the Congolese army or the Rwandan army, a major corporate employer in South Kivu is Canada's gold mining company, Banro. I visited them to hear about their environmental programs. Their representatives argue, perhaps unsurprisingly, that the solution to the conflict is legitimate business - too many unemployed people and too many weapons lead to violence. The day after my visit, I ask my students:

"What's Banro's reputation?"

"Good," one student says.

"Bad," another says. "They have a concession in Itombwe, which is a reserve, a primary forest."

"Is it currently mined?" I ask.

"Yes, but not by them. It's currently controlled by armed groups, but it'll be necessary to chase them out."

A female student laughs when he says that. "Oh, just chase them out, will you?"

"Yes, we have to chase them out. They are there illegally."

A debate ensues between the realist and the conservationist, who explains to me that the government granted a wide range of concessions to corporations like Banro, concessions that are currently being mined by artisans under the supervision of armed groups. The realist shares Banro's view and wants the mines to be in corporate hands, while the conservationist wants to extend the protected forest.

And Congolese conservationists are very serious indeed. At the end of my first week, I visit the gorillas in the Kahuzi Biega National Park. Eight visitors, accompanied by four rangers, visit with a gorilla family (in this case Chimanuka and family) for an hour. The rangers look tough, clearly know and love the gorillas, and have obviously seen a lot. The main office has a shrine of skulls of gorillas killed during the war - most of them, it seems, were killed between 1996 and 1998.
On my last day, my students ask me what I think of them. When I tell them I was impressed with their focus and attention spans, they seem satisfied. They ask what was negative about teaching there. Mostly technology and infrastructure, I say. I had no complaints about the students. As I'm saying this, a student's cell phone rings, and we laugh. "No complaints," I repeat.

\section{Observations from teaching in the Kivus}

I had a few observations that I didn't share with my students. I think my students, and my colleagues, are highly politically aware and forced, by the context, to be cautious about how much they express. In the summer of 2011, campaigning for the November 2011 presidential election had already begun. Between the lines, I heard a bitter understanding that the current president, Joseph Kabila, was going to do whatever was necessary to ensure that he would stay the president. Kabila had won the 2006 elections with massive electoral support from the east, including Bukavu and likely including my students, as someone who was from the east and would be able to bring peace to the region. And while it is possible to talk about "post-conflict Congo," the east has been disappointed by Kabila's performance. The 2011 elections turned out according to the bitter predictions I had heard in the summer. Amid low turnout and accusations of intimidation and fraud, Joseph Kabila returned to the presidency.

My students also took it for granted that anyone who would teach in the Congo would know a great deal about it. No one was the least bit impressed when I used examples from Congolese history or economics or the recent war to illustrate points. They just expected their professors, even foreign ones, to know these details, and they think of the Congo as an important country, even if it's not currently on its feet. On the other hand, they were very curious and interested about the rest of the world, including my own background. My parents are from Kerala, a state in India that is often used as an example of excellent health and education outcomes without concomitant economic growth, a development model that, like Cuba, is based on popular mobilization and, of course, education. When I explained one of the critiques of the Kerala model, that excellent education without sufficient growth in employment means that millions of Kerala's children end up working outside of the state, my students laughed. "Like you!" they said.

The other impression that has stayed with me was the power of Western frames. Those who tell stories of "local corruption" had a lot more time to work on my students than I did with the story of external colonialism and predation. The same facts, the same experiences, can be fit into a colonial narrative of eternal chaos and ethnic conflict or into an anti-imperialist narrative of interference and plunder. Kevin Dunn was right: the West's Imagining the Congo has great power, even in the Congo. I had expected to start with a radical economic analysis of underdevelopment in the Congo and go into depth in history and strategy. Instead, I had to start as I often do in North America: by arguing for a diversity of views besides just the neoliberal one and building up the arguments 
brick-by-brick from there. My task was to take these future and current managers to a place where they could consider other policy options besides the neoliberal package of privatization, low taxes, deregulation, and favouring the private sector. In my class it meant introducing Ha-Joon Chang's ideas about how the developed countries actually developed, but doing so gently. For these students, I learned, the power of Western frames was matched by the power of political context: I had to be at least as cautious as they were about how we discussed politics and economics.

I served as external examiner on a few of the program's Master's theses in 2012. By the end of that year, "post-conflict" Congo had flared up again. Another Rwandan-supported rebellion, named M23, had taken over the capital of North Kivu, Goma, and was promising to march on Bukavu. In November of 2012, I heard that my students were scared, that foreigners were leaving. By December, the rebels had left Goma and were negotiating with the Congolese government in Uganda, their ultimate goal probably the partition of the Congo and some legal status for Rwanda's de facto control of the Kivus. More people displaced, more lives ruined, more foreign interference, and more development time lost.

Which, to Katcho and Gustave, just means more time they need to hurry to make up. The invitation to foreign scholars to go teach is still open, and they are going to try to keep teaching, whatever is going on.

\section{References}

AfriMap. 2009. The Democratic Republic of Congo: Effective Delivery of Public Services in the Education Sector. http://www.afrimap.org/english/images/report/AfriMAP DRC Edn full_EN.pdf

Chang, Ha-Joon. 2007. Bad Samaritans: The Myth of Free Trade and the Secret History of Capitalism. New York: Bloomsbury Press.

Dunn, Kevin C. 2003. Imagining the Congo: The International Relations of Identity. New York: Palgrave Macmillan.

Moyo, Dambisa. 2009. Dead Aid: Why Aid is Not Working and How There Is a Better Way for Africa. New York: Farrar, Straus and Giroux.

World Bank. 2005. Education in the Democratic Republic of Congo: Priorities and Options for Regeneration. A World Bank Country Study.

Yates, Barbara. 1963. "Structural Problems in Education in the Congo (Leopoldville)". Comparative Education Review. vol. 7 no. 2 Oct. 1963, pp. 152-162.

Yates, Barbara. 1980. "White Views of Black Minds: Schooling in King Leopold's Congo." History of Education Quarterly. vol. 20, no. 1 spring 1980 , pp. 27-50.

\section{Notes}

1 An unpublished note from colonial governor Ryckmans to M. Van Bilsen dated April 19, 1955. Cited in Rene Lemarchand. 1964. Political Awakening in the Belgian Congo. University of California Press. p. 133.

2 Lemarchand, p. 136.

3 J.S. Harris, "Education in the Belgian Congo," Journal of Negro Education, XV (Summer, 1946), p. 426. Cited in Lemarchand, p. 143. 